characteristics of pupils' physical and mental development; taking into account interests, requests, desires, inclinations, worldview, emotional and sensory sphere and a pupil's status in a team; the possibility of individualisation of the content, methods and pace of educational activities of each pupil individually and all together; creation in the conditions of extracurricular work on the development of English writing competence subject-to-subject interaction between a teacher and pupils, as well as pupils among themselves; combining different forms, methods and tools for the development of English writing competence; use of modern information technologies, means of Internet telephony, etc.

Key words: extracurricular work, forms of organisation of extracurricular activities, English writing competence, general secondary education institutions.

Дата надходження статті: 14.01.2021 p. Реценнзент: доктор педагогічних наук, професор Майер Н. В.

УДК 17.022.1:37.012

DOI https://doi.org/10.37915/pa.vi48.186

Христенко О. М.,

orcid.org/0000-0001-6036-2829

\title{
ЗАРУБІЖНИЙ ДОСВІД ДОСДІДЖЕННЯ ЦІННОСТЕЙ В ОСВІТНЬОМУ КОНТЕКСТІ
}

Сучасне людство зустрічае низку складних викликів, таких як поширеність (особливо серед молоді) депресій, суїцидів, наркоманії, злочинності та інших негативних соціальних явищ, які безпосередньо детерміновані відсутністю належної системи цінностей у сучасної людини та суспільства. Для украӥнськой наукової спільноти важливим є вивчення зарубіжного досвіду дослідження цุінностей, оскільки цее питання (як і перелічені виклики сучасній цุивілізації) носить глобальний характер і мусить вирішуватися у світовій науковій інтеграції. У даній статті проаналізовано особливості й тенденцї розвитку зарубіжних досліджень ціннісної проблематики в освітньому контексті. Визначено сутнісну структуру поняття "цінності», яка, зокрема, містить: принциии або якості, щз виражають кардинальні чесноти, які роблять людину гідною уваги $і$ поваги; переконання про те, ще є важливим у житті та котрі контролюють поведінку людей; духовні, ідеальні, вічні категорії, які відображають вищі изілі, ідеали, до яких прагнуть люди; джерело позитивних емоцій та натхнення до етичних дій; критерії індивідуальних та колективних оцінок дій та переконань інших людей; індикатор совісті й характеру людини, що формується шллхом самоосвіти й самовдосконалення; структуровані мотиви особистості. Охарактеризовано такі тенденції розвитку изіннісної проблематики, як: розширення відповідальності за формування моральних изінностей на основні суспільні інститути (щкола, церква, неурядові організаціï), розвиток різних форм соизільної активності / доброчинності як вияв прикладного характеру цінностей у контексті сучасної зарубіжної науки та практики. Досліднцьькі результати вчених спонукають до подальшого аналізу сприйняття моральних иінностей студентською молоддю задля визначення ключових сфер самовдосконалення молодої людини.

Ключові слова: ицінності, моральні ицінності, особистість, заклад освіти, компетентність доброчинності.

Постановка проблеми. Очевидно, що стан духовної культури й морадьності суспільства в цілому світі викдикає занепокоєння. Занепад духовних цінностей став наслідком прагматизації життя, пропаганди насилдя, нехтування правовими, моральними, соціальними нормами і виріс до масштабів глобальної соціальної проблеми [4, с. 70]. Освіта, яка виступає фундаментом імплементації ключових ініціатив, потребуе відповідних дослідницьких пошуків 3 метою формування особистості

*C) Христенко О. М.

us 
на адекватних та справжніх цінностях.

Аналіз досліджень. Проблематику цінностей у різних аспектах репрезентують чимало зарубіжних учених, серед яких А. Гернандо, І. Діез-Вега, Г. Йоас, Д. Кольберг, М. Лопез дел Гіеро, А. Макінтайр, Г. Олпорт, Т. Парсон, Ш. Шварц, Е. Шпрангер, М. Штейн та низка інших мислителів. Їхні праці показують розуміння представниками інших націй/культур ціннісного підходу в окремих сферах життя.

Мета статті - проаналізувати особливості й тенденції розвитку зарубіжних досліджень ціннісної проблематики в освітньому контексті.

Виклад основного матеріалу. Репрезентуючи етимологію слова «цінність» як похідного від латинської та запозиченого 3 англо-французької, словник Мерріам Вебстер трактує його значення як «вартий», «високоякісний», «добрий» [10]. Відтак, дефініція цінностей передбачає принцип або якість, самоцінну (бажану). Цікаво, що джерело подає нам синонімічний ряд даного поняття, де знаходимо кардинадьні чесноти (виділені ще Платоном), серед яких мужність, справедливість, розсудливість, помірність, стійкість.

Оксфордський словник визначає цінності як переконання про те, що є правдивим і неправдивим та що $є$ важдивим у житті. У цьому контексті знаходимо поняття «моральні цінності», «традиційні цінності», «сімейні цінності». Так, останні передбачають переконання про значущість високих моральних стандартів й традиційний сімейний союз матері, батька і дітей. Наприклад, у США сімейні цінності є сильно пов'язаними 3 консервативними християнськими цінностями. Водночас, система консервативних цінностей не пов'язана із сучасним лібералізмом [13].

Дещо подібну дефініцію «цінностей» зустрічаємо і в Кембриджському словнику, де вони трактуються як переконання дюдей про те, що е правильним, неправильним і найважливішим у різних сферах життя, та котрі контролюють поведінку людей [12]. Дане джерело представляе цінності 3 позиції їх класифікації на основні (спільні), культурні, соціальні, традиційні тощо. При цьому вони поруч 3 культурою виступають об'єднавчим чинником у ділових та інших відносинах.

Згідно 3 тлумаченням у німецькому словнику Дудена, цінності виражають позитивну сутність чогось або когось [14]. Відтак, вони постають як духовні, ідеальні та вічні категорії, що підкреслюе об'єктивістський підхід до трактування цінностей у західній традиції. Аналізуючи зміст поняття «цінності» в лінгвістичному контексті, можемо простежити закономірність детермінованості даної дефініції характерною специфікою конкретної мови, що, серед іншого, виражає світоглядно-ментальні риси й культуру носіїв цієї мови. Так, французький словник Лероберта виявляе істинність (справжність), красу та добро як неодмінні властивості цінностей, котрі, у свою чергу, поділяються на моральні, соціальні, естетичні. Характерно, що поняття «цінності» асоціюється 3 такими чеснотами: хоробрість, непохитність, героїзм, благородність, щедрість, гідність, велич (душі) [11].

Низка німецьких дослідників розширюють зміст цінностей на основі власної національно-духовно-інтелектуальної спадщини. Так, Ш. Шварц, простежуючи етимодогію даного поняття із витоків старонімецької мови, трактує цінності як стандарти ідентифікації, критерії індивідуадьних та колективних оцінок дій та переконань інших, а також як цілі, до яких прагнуть дюди, та принципи, що керують їхнім життям [5, с. 247; 9, c. 12].

Т. Парсон репрезентує цінності як загальноприйняті бажані цілі, ідеї, складові культури суспільства, а також як переконання людей, що мають специфічний когнітивний зміст та асоціюються 3 позитивно емоційними аспектами життя [5, с. 247]. Водночас, на думку вченого, саме цінності сприяють прийняттю рішень у конфліктних ситуаціях, виражаючи ідеї «бажаного» для конкретної людини. Такий підхід увиразнює безпосередню практичну складову даної дефініції та визначає відповідні освітні цілі стосовно формування системи цінностей дітей і молоді. 
Апріорно моральну сутність цінностей підкреслюе М. Штейн, зазначивши, що вони становлять зміст морадьних концепції та етики в цілому. Погоджуемося 3 думкою авторки про те, що індивідуальні цінності виступають індикатором совісті й характеру людини. Відтак, аналізуючи вчинки, поведінку та висловлювання особи, можна моделювати їі ціннісні пріоритети (що особливо важливо в умовах закладу освіти, метою якого повинно бути формування відповідної системи цінностей молодого покоління). До речі, М. Штейн уточнює цей взаємозв'язок та, опираючись на ідеї Т. Парсона, зазначає, що дотримання дюдиною власних цінностей супроводжується позитивними почуттями й виявляє так звану добру совість i, навпаки, - нехтування своїми моральними стандартами детермінує негативні емоції як прояв так званої поганої совісті [9, с. 12].

Щоб у дітей формувалися ціннісні основи «доброї совісті», їхнє соціальне оточення повинно «випромінювати» моральність у практичному аспекті - в діях, манерах, словах, виборі... Як стверджує Г. Йоас, просто граючись й перебуваючи 3 іншими соціальними партнерами, діти вже вивчають цінності та норми [5, с. 248]. Відтак, досліджуючи походження цінностей, вчений констатуе їх прив'язаність до дюдської життедіяльності й наполягає на тому, що формування системи індивідуальних вартостей не відбувається винятково через раціонадьне аргументоване розуміння, а швидше шляхом самоосвіти й самовдосконалення [5, с. 251].

Це твердження співзвучне з науковими ідеями Е. Шпрангера, який розробив модель цінностей у значенні форми пізнання світу або форми життя. Й сьогодні, шукаючи оптимальні способи розвитку позитивного в людині, ми можемо опиратися на його типодогію світопізнання, якій відповідають шість типів особистості 3 конкретними цінностями. Очевидно, що Е. Шпрангер визначає теоретичний, економічний, естетичний, соціальний, політичний та релігійний типи особистості, виходячи $з$ емпіричних даних, а не абстрактного теоретизування. Поведінка людей, детермінована їхніми ціннісними пріоритетами, стала основною підставою ддя вченого структурувати відповідним чином систему індивідуальних цінностей особистості.

У контексті дослідження процесу становлення особистості Г. Олпорт розвиває модель Е. Шпрангера, означивши цінності основою індивідуальної філософії життя й структурованими мотивами [1, с.51]. Сам Е. Шпрангер аналізує сильні та слабкі сторони кожного типу дюдей, зазначаючи, що ніхто не може реалізувати всі цінності. Переваги тієї чи іншої системи вартостей, на переконання вченого, випливають із їх придатності до певних форм життя. Наприклад, віра, дюбов і надія як цінності релігійного типу за Е. Шпрангером виражають основні умови життя, а релігійність функціонуе як принцип виживання. Характерно, що сам Е. Шпрангер визначає близькість вихователя (який / яка) формуе цінності в підростаючого покодіння) вдасне до релігійного типу [8, с. 727], що має забезпечити повноцінний духовний розвиток особистості дитини.

Вартою особливої уваги $є$ характеристика Е. Шпрангером соціального типу особистості, якому притаманна висока цінність іншої дюдини (ближнього / ближньої), що детермінує постійну готовність до філантропічної діяльності. Але, на думку вченого, існуе зворотній бік такої ціннісної орієнтації, а саме надмір ідеалізму та оптимізму, що змушуе репрезентаторів соціального типу думати краще про людей, ніж це $є$ в реальності [8, с. 727-728]. Ці дослідження сприяють розробці виховних концепцій в частині визначення співвідношення, взаємовпдиву та пріоритетності цінностей різних типів людини, що є необхідним для формування всебічно і гармонійно розвинутої особистості.

За резудьтатами нашого дослідження визначено сутнісну структуру поняття «цінності» у контексті зарубіжної науки (табл. 1). 


\section{Дефініція поняття «цінності» у працях зарубіжних дослідників й академічних енцикдопедичних виданнях / словниках}

\begin{tabular}{|l|c|c|c|c|c|c|c|}
\hline \multicolumn{1}{|c|}{ Структура поняття } & 1 & 2 & 3 & 4 & 5 & 6 & 7 \\
Автор Ш. Шварц (S. Shwarz) & & & + & & + & & \\
\hline Т. Парсон (Т. Parson) & & & & + & & + & \\
\hline М. Штейн (M. Stein) & & & & & & + & \\
\hline Г. Йоас (Н. Joas) & & & & & & + & + \\
\hline Е. Шпрангер (E. Spranger) & & + & & & & & + \\
\hline Г. Олпорт (G. Allport) & & + & & & + & & + \\
\hline А. Кольберг (L. Kohlberg) & & + & & & & + & \\
\hline А. Макінтайр (А. MacIntyre) & + & & & & & & + \\
\hline Словник Мерріам Вебстер & + & & & & + & & \\
\hline Оксфордський словник & & + & & & + & & \\
\hline Кембриджський словник & & + & & & + & & \\
\hline Словник Дудена & & & + & + & & & \\
\hline Словник Лероберта & + & & & + & & & \\
\hline
\end{tabular}

Примітки: 1. Принципи або якості, що виражають кардинальні чесноти, які роблять дюдину гідною уваги і поваги. 2. Переконання про те, що $є$ важливим, правильним у житті та котрі контролюють поведінку людей. 3. Духовні, ідеальні, вічні категорії, які відображають вищі цілі, ідеали, до яких прагнуть люди. 4. Джерело позитивних емоцій та натхнення до етичних дій. 5. Критерії індивідуальних та колективних оцінок дій та переконань інших людей. 6. Індикатор совісті й характеру людини, що формується шляхом самоосвіти й самовдосконалення. 7. Форма життя, основа індивідуальної філософії життя, структуровані мотиви особистості.

У науковій спадщині американського вченого А. Кольберга концепт цінностей пов'язаний із проблемою морального виховання. Виділяючи три рівні морального розвитку особистості, дослідник наголошує, що його поступальність виражається у взаємовпдиві суспільних та індивідуальних цінностей. Так, на другому рівні суспільна загальноприйнята мораль домінуе над особистісними цінностями, а на третьому людина сама вибудовує власну систему етичних принципів, цінностей, норм і свідомо їх дотримується [2, с. 7].

Нові моральні засади розвитку особистості та суспільства передбачає етика доброчинності Е. Макінтайра. Базовими цінностями дюдини в контексті даної концепції виступають: великодушність, дружба, мужність, приязність, чесність, сміливість, справедливість, правдивість. Підтримуемо пропозицію Е. Макінтайра, який рекомендуе формувати такі моральні цінності (чесноти) шляхом творення докальних форм соціальності - невеликих місцевих громад, шкіл, шпиталів, парафій [там само, с. 9].

Якщо розгдядати дані концепції в освітньому дискурсі, то їх ідеї відповідають навчально-виховним цілям щодо формування компетентності доброчинності, яка суттєво вдосконадюе професійну підготовку майбутніх фахівців. У нашому розумінні компетентність доброчинності передбачає, зокрема, цінності: повага і мидосердя до бідних, обездолених, дюдей 3 обмеженими мождивостями; особистісне духовноморальне зростання шляхом практикування доброчинності [3, с. 36]. Одним з ефективних шляхів формування компетентності доброчинності в умовах закладів вищої освіти виступає волонтерська діяльність студентів у співпраці / співорганізації з викладачами, адміністрацією університету. Чималий досвід щодо впровадження цінностей піклування й доброчинності на практиці репрезентують учасники постійно діючого загальноуніверситетського волонтерського руху Тернопільського національного медичного університету «Misericordia». Студенти проводять низку заходів, акцій 3 метою 
допомоги бідним, малозабезпеченим, багатодітним сім'ям, вагітним жінкам, дітямсиротам, дюдям похилого віку та інвалідам. Окремим напрямом волонтерської діяльності майбутніх лікарів є реалізація наукових та освітніх програм задля надання допомоги школярам щодо формування навичок здоров'язбереження. Крім цього, студентиіноземці проводять безкоштовні уроки англійської мови для учнів сільських шкіл Тернопілля, спільно з українськими студентами - благодійні акції для вихованців дитячих будинків та спеціалізованих шкіл, де навчаються діти з особливими потребами [7].

Отже, участь у волонтерській діяльності - це можливість для студентів формувати й реалізовувати на практиці базові для дікарської професії цінності: чуйність, милосердя, самовідданість, безкорисдивість... Відтак, волонтерство, яке в сучасних реаліях стає частиною культури і світогляду української нації, у світлі етики доброчинності Е. Макінтайра виступає ціннісним пріоритетом у формуванні особистості майбутніх дікарів, готових до здійснення своєї високої місії по всьому світу.

Незамінним засобом духовного розвитку особистості й формування іï етичних цінностей виступає релігійна мораль. Вивчення, зокрема, християнської етики сприяє розвитку дійсного релігійного досвіду, який, за словами Е.Фромма, полягає у «відновленні дюдиною божественного образу своєї особистості», формуванні ціннісних орієнтирів і морального еталону життєдіяльності [4, с.74]. Отож, майже в усіх країнах Європи традиційно зберігається релігійна освіта як окремий предмет початкової і середньої ланки освіти (Данія, Великобританія, Ірландія, Швеція), або переважно як конфесійне навчання, чи релігієзнавчий предмет, що подає інформацію про різні релігіі / предмет гуманітарного циклу (Бельгія, Франція, Швейцарія). Також прищеплення цінностей релігійної моралі дітям і молоді відбувається у недільних школах при церквах, монастирях, приватних школах [2, с. 12].

Серед засобів розвитку моральних, духовних цінностей студентської молоді українах Європи та Америки самобутне місце посідають суспільно-політичні дисципліни на кшталт «Демократія в школі», «Громадянознавство». Так, у США реалізовується базовий виховний проект «Character caunts!», очікуваними результатами якого мають стати «шість стовпів» характеру: повага, надійність, справедливість, відповідальність, турботливість, громадянськість. Як зазначає О. Сухомлинська, даний проєкт грунтується на загальнолюдських цінностях і виступає загальносуспільною, а не лише педагогічною, освітньою метою [там само, с. 13].

Власне, така тенденція притаманна і для зарубіжної вищої шкоди, адже, за словами А. Гернандо, І. Діез-Вега, М. Лопез дел Гіеро та ін., суспільство вимагає університетської освіти, базованої на етичних принципах, а виховання моральних цінностей є відповідадьністю університетів [6]. Автори репрезентують результати дослідження, що є важливими для розуміння тенденцій розвитку етичних цінностей у молодіжному середовищі. Так, студенти медичних коледжів Іспанії сприймають відповідальність і повагу як найваждивіші цінності, а солідарність та соціальну участь як найменш важливі.

Дослідники зазначають, що, на переконання студентів, гармонію міжособистісних відносин можуть забезпечити такі цінності: повага до інших (їхніх погдядів), урахування побажань інших, ненав'язування, відповідальність перед однокурсниками, викладачами, бережливе ставлення до навколишнього середовища і природи, ощадливість, допомога, конфіденційність, співчутливість, чемність, уважність, терпеливість, солідарність, щедрість, справедливість, свобода від забобонів, емпатійність (до складних ситуацій/дюдей). У цьому контексті ставлення до себе студенти трактують через призму таких цінностей: добре самопочуття, дитячий досвід як основа формування власного «Я», самооцінка, самоповага, самовдосконалення, відповідальність за себе, емоційна рівновага, працьовитість, постійність, пріоритетність важливих справ, організованість, навчання. За результатами дослідження іспанських учених, у ставленні до загальноприйнятих правид і норм студенти керуються цінностями, серед яких: справедливість, дотримання 
власних принципів / цінностей та повага до інших, виконання правил, соціальна активність [6].

Висновки. Отже, зарубіжні дослідники репрезентують дефініцію цінностей, що виражає тісний зв'язок між етичними вартостями, які асоціюються 3 почуттям доброго, позитивного, та емоційною рівновагою особистості. Виразними є і такі тенденції розвитку ціннісної проблематики: розширення відповідальності за формування моральних цінностей на основні суспільні інститути (школа, церква, неурядові організаціi), розвиток різних форм соціальної активності / доброчинності як вияв прикладного характеру цінностей у контексті сучасної зарубіжної науки та практики; збільшення міждисциплінарних досліджень фізичного, психічного, духовного, соціального здоров'я як базової цінності в сучасних умовах пандемії. Дослідницькі результати вчених спонукають до подальшого аналізу сприйняття морадьних цінностей студентами задля визначення кдючових сфер самовдосконалення молодої дюдини.

\section{Список використаних джерел:}

1. Олпорт Г. В. Становление личности. Избранные труды / под. ред. Д. А. Аеонтьева. Москва : Смысл, 2002. 462 с.

2. Сухомлинська О.В. Концептуалізація ідей про виховання моральності в сучасній Україні. Шкільний світ. 2015. Т. 4 (Вип. 708). С. 4-20.

3. Христенко О. Феномен жіночого християнського служіння у контексті сучасної філософії освіти. European philosophical and historical discourse. 2018. Volume 4. Issue 1. Pp. 31-38.

4. Якухно I. І. Вивчення основ християнської етики в закладах освіти. Педагогічний альманах: зб. наук. пр. / редкол. В. В. Кузьменко (голова) та ін. Херсон: КВНЗ «Херсонська академія $\begin{array}{lllll}\text { неперервної } 2019 . & \text { випути», } 41 . & \text { C. 69-75. URL: }\end{array}$ http://nbuv.gov.ua/UJRN/pedalm 20194112

5. Halil U. H. Vom Wert der Werte in der Lebenserfahrung: Andere Kulturen - andere Werte? Bildungsinstitutionen, Kooperationen Beiträge aus Theorie und Praxis Herausgeber / Red. Dr. Annegret Erbes. Berlin: Deutsches Rotes Kreuz e.V., 2013. S. 247-261.

6. Hernando A., Diez-Vega I., Lopez del Hierro M. at al. Ethical values in college education: a mixedmethods pilot study to assess health sciences students' perceptions. BMC Medical Education. 2018. 18:289. URL: https://doi.org/10.1186/s12909-018-1396-7

7. Misericordia. Тернопільський національний медичний університет. URL: https://misericordia.tdmu.edu.ua/pro-nas

8. Neumann D. Ein Klassiker der Pädagogik in evolutionärer Perspektive: Eduard Sprangers «Lebensformen» im Lichte der modernen Biologie. Zeitschrift für Pädagogik. 2002. № 48 (5). S. 720 740. URL: https://www.pedocs.de/frontdoor.php?source opus $=3858$

9. Stein M. Wertetransmission als Aufgabe der Werte und Wertebildung in Familien. Bildungsinstitutionen, Kooperationen Beiträge aus Theorie und Praxis Herausgeber / Red. Dr. Annegret Erbes. Berlin: Deutsches Rotes Kreuz e.V., 2013. S. 11-24.

10. The Merriam-Webster Dictionary. Springfield: Merriam-Webster Incorporation, 2016. 960 p. URL: https://www.merriam-webster.com/dictionary/value

11. Valeur. Le Robert Dictionnaire. URL: https://dictionnaire.lerobert.com/definition/valeur

12. Values. Cambridge Advanced Learner's Dictionary. Cambridge: Cambridge University Press, 2008. 1814 p. URL: https://dictionary.cambridge.org/dictionary/english/values

13. Value. Oxford Dictionaries. Oxford: Oxford University Press, 2010. 2112 p. URL: https://en.oxforddictionaries.com/definition/value

14. Wert. Duden Wörterbuch. URL: https://www.duden.de/suchen/dudenonline/wert

\section{References:}

1. Olport, G. V. (2002). Stanovlenie lichnosti. Izbrannye trudy [Personality formation. Selected works]. Moskva: Smysl [in Russian].

2. Sukhomlynska, O. V. (2015). Kontseptualizatsiia idei pro vykhovannia moralnosti v suchasnii Ukraini [Conceptualization of ideas about morality education in modern Ukraine]. Shkilnyi svit, 4 (708), 4-20 [in Ukrainian]. 
3. Khrystenko, O. (2018). Fenomen zhinochoho khrystyianskoho sluzhinnia u konteksti suchasnoi filosofii osvity [The phenomenon of women's Christian ministry in the context of modern philosophy of education]. European philosophical and historical discourse, 4 (1), 31-38 [in Ukrainian].

4. Yakukhno, I. I. (2019). Vyvchennia osnov khrystyianskoi etyky v zakladakh osvity [Study of the basics of Christian ethics in educational institutions]. Pedahohichnyi almanakh, 41, 69-75. Retrieved from http://nbuv.gov.ua/UIRN/pedalm 20194112 [in Ukrainian].

5. Halil, U. H. (2013). Vom Wert der Werte in der Lebenserfahrung: Andere Kulturen - andere Werte? Bildungsinstitutionen, Kooperationen Beiträge aus Theorie und Praxis Herausgeber, 247-261 [in German].

6. Hernando, A., Diez-Vega, I., Lopez del Hierro, M., Martines-Alsina, N., Diaz-Meco, R., Busto, M., \& Gonzalez-Cuevas, G. (2018). Ethical values in college education: a mixed-methods pilot study to assess health sciences students' perceptions. BMC Medical Education, 18, 289. Retrieved from https://doi.org/10.1186/s12909-018-1396-7 [in English].

7. Misericordia. Ternopil National Medical University. Retrieved from https://misericordia.tdmu.edu.ua/pro-nas [in Ukrainian].

8. Neumann, D. (2002). Ein Klassiker der Pädagogik in evolutionärer Perspektive: Eduard Sprangers "Lebensformen" im Lichte der modernen Biologie. Zeitschrift für Pädagogik, 48 (5), 720-740. Retrieved from https://www.pedocs.de/frontdoor.php?source opus=3858 [in German].

9. Stein, M. (2013). Wertetransmission als Aufgabe der Werte und Wertebildung in Familien. Bildungsinstitutionen, Kooperationen Beiträge aus Theorie und Praxis Herausgeber, 11-24 [in German].

10. The Merriam-Webster Dictionary. (2016). Springfield: Merriam-Webster Incorporation. Retrieved from https://www.merriam-webster.com/dictionary/value [in English].

11. Le Robert Dictionnaire. Valeur. Retrieved from https://dictionnaire.lerobert.com/definition/valeur [in French].

12. Cambridge Advanced Learner's Dictionary. (2008). Values. Cambridge: Cambridge University Press. Retrieved from https://dictionary.cambridge.org/dictionary/english/values [in English].

13. Oxford Dictionaries. (2010). Value. Oxford: Oxford University Press. Retrieved from https://en.oxforddictionaries.com/definition/value [in English].

14. Duden Wörterbuch. Wert. Retrieved from https://www.duden.de/suchen/dudenonline/wert [in German].

Khrystenko O. M., orcid.org/0000-0001-6036-2829

\section{FOREIGN EXPERIENCE OF RESEARCH OF VALUES IN THE EDUCATIONAL CONTEXT}

Modern humanity faces a number of complex challenges, such as the prevalence (especially among young people) of depression, suicide, drug addiction, crime and other negative social phenomena, which are directly determined by the lack of a proper system of values of modern human and society. It is important for the Ukrainian scientific community to study foreign experience in the investigation of values as this issue (as well as the listed challenges of modern civilization) is global in nature and must be solved in global scientific integration. This article analyzes the features and trends of development of foreign studies of value issues in the educational context. The essential structure of the concept of «value» is defined, which, in particular, includes: principles or qualities that express cardinal virtues that make a person worthy of attention and respect; persuasions about what is important in life and what controls people's behavior; spiritual, ideal, eternal categories that reflect the higher goals, ideals to which people aspire; a source of positive emotions and inspiration for ethical actions; criteria for individual and collective assessments of other people's actions and beliefs; an indicator of a person's conscience and character, formed by self-education and self-improvement; structured motives of personality. The tendencies of development of value problems are characterized, namely: expansion of responsibility for forming of moral values on the basic public institutes (school, church, non-governmental organizations); development of various forms of social activity / charity as a manifestation of the applied nature of values in the context of modern foreign science and practice. Research results of scientists encourage further analysis of the perception of moral values by student youth in order to identify key areas of self-improvement of young people.

Key words: values, moral values, personality, educational institution, competence of charity. 